\title{
ON THE 75TH ANNIVERSARY OF THE BEGINNING OF THE NUREMBERG TRIALS AND THE CREATION OF THE NUREMBERG CODE: GLOBAL RELEVANCE AND ENDURING LESSONS
}

Chuchalin $\mathrm{AG}^{1} \otimes$, Sayamov YuN²

Pirogov Russian National Research Medical University, Moscow, Russia

2 Lomonosov Moscow State University, Moscow, Russia

The article reveals the significance of the Nuremberg Trials for rethinking the moral foundations of medicine, investigates the role of the Nuremberg Code in the establishment of voluntary informed consent as a mandatory component of clinical trials and procedures and assesses the impact thereof on the international legal regulation of healthcare. The authors emphasize the importance of the Nuremberg lessons for understanding the ethical challenges that came into foreground in the 21 st century due to the development of artificial intelligence, human genome editing technologies and the emergence of the new forms of parenting largely backed by the new reproductive technologies.

Keywords: Nuremberg trials, Nuremberg code, informed consent

Author contribution: Research concept and design — Chuchalin AG; text writing and editing — Sayamov YuN.

$\triangle$ Correspondence should be addressed: Alexander G. Chuchalin

Ostrovityanova st. 1, Moscow, 117997; Chuchalin@inbox.ru

Received: 12.02.2021 Accepted: 25.03.2021 Published online: 31.03.2021

DOI: $10.24075 /$ medet.2021.002

\section{К 75-ЛЕТИЮ НАЧАЛА НЮРНБЕРГСКИХ ПРОЦЕССОВ И СОЗДАНИЯ НЮРНБЕРГСКОГО КОДЕКСА: ГЛОБАЛЬНОЕ ЗНАЧЕНИЕ И НЕПРЕХОДЯЩИЕ УРОКИ}

\author{
А. Г. Чучалин ${ }^{1 凶}$, Ю. Н. Саямов \\ ${ }^{1}$ Российский национальный исследовательский медицинский университет имени Н. И. Пирогова, Москва, Россия \\ ${ }^{2}$ Московский государственный университет им. М. В. Ломоносова, Москва, Россия
}

В статье раскрывается значение Нюрнбергского процесса для переосмысления нравственных оснований медицины; рассматривается роль Нюрнбергского кодекса в становлении добровольного информированного согласия в клинической практике и в клинических исследованиях, а также его влияние на международное нормативно-правовое регулирование сферы здравоохранения. Авторы акцентируют внимание на значении уроков Нюрнберга для понимания этических вызовов, которые актуализировались в XXI веке в результате развития технологий искусственного интеллекта, редактирования генома человека и становления новых форм родительства, во многом связанных с достижениями новых репродуктивных технологий.

Ключевые слова: Нюрнбергский процесс, Нюрнбергский кодекс, добровольное информированное согласие

Вклад авторов: концепция и дизайн исследования - Чучалин А. Г.; написание и редактирование текста — Саямов Ю. Н.

$\triangle$ Для корреспонденции: Чучалин Александр Григорьевич

ул. Островитянова, д. 1, г. Москва, 117997; Chuchalin@inbox.ru

Статья получена: 12.02.2021 Статья принята к печати: 25.03.2021 Опубликована онлайн: 31.03 .2021

DOI: $10.24075 /$ medet.2021.002

The year 2020 was marked with the $75^{\text {th }}$ anniversary of the Great Victory and the subsequent anniversaries of events that could not have happened without this historic achievement. The war unprecedented in its monstrosity, victim count and scale of destruction generated a common desire and firm determination to never again allow such a catastrophe and to punish the guilty. The desire transformed into the International Military Tribunal (IMT) established in 1946 to try the ideologists and leaders of Nazism and militarism guilty of the horrific crimes. This was a trial by the peoples.

Celebrating the $75^{\text {th }}$ anniversary of these events, it is necessary to dwell on the global significance and enduring lessons of the IMT's condemnation of the Nazi leaders who unleashed the world massacre, and specifically discuss the atrocities committed under their leadership, including in the field of medicine. This discussion seems especially relevant today, in the light of the ongoing processes and emergence of the new threats and challenges affecting health, safety of people and human rights.

The International Military Tribunal and subsequent trials took place in the Bavarian city of Nuremberg, where Nazis held their congresses and declared the insane misanthropic ideas and the right of the Germans to dominate the world as a superior race.
The Nuremberg Trials became the starting point of a new era in the development of world civilization and global legal consciousness. They established the legal foundations and principles of the post-war world order, which were adopted by the newly created UN and essentially back the current understanding of human rights and freedoms.

Nuremberg Trials formulated the concepts of crimes against peace and humanity, legally qualified and condemned the unprecedented acts by the criminal Hitlerite regime, such as the mass extermination of people in the "death factories", inhuman treatment of the civilian population and concentration camp prisoners, medical experiments involving the prisoners.

The results of the Nuremberg Trials boosted evolution of the international law and lead to a real breakthrough in the process of regulations development. They gave rise to the new legal culture that enshrined the ideas of peace, prevention of war and protection of human rights and freedoms in the national legislations.

The lessons of Nuremberg include both the IMT outcomes and the results of the twelve Nuremberg trials that followed. Since Nuremberg was in the American occupation zone, the Allies agreed that the proceedings will be supported by the American military tribunal. Among them, the trial of the Nazi killer doctors occupies a special place. It lasted from December 
9, 1946 to August 20, 1947. The hall of the Nuremberg Palace of Justice selected for this trial was that where the key war criminals of the Third Reich were tried. Twenty most odious Nazi criminal doctors, 2 medical officials and 1 lawyer were accused at the trial, but that is not the only and, probably, not the most important fact underpinning the significance of these proceedings. There is an outcome of this trial that is at least no less significant, namely, the development of the Nuremberg Medical Code. It relied on the proceedings' results and was the first document since the works of Hippocrates to establish the principles of medical ethics, which remain current to this day. There were 1471 documents reviewed and 177 participants of the experiments [1] heard at the trial. The evidence and the testimonies revealed a horrifying picture of experiments that forcefully involved Nazi concentration camp prisoners stripped of all rights. Following requests from the air and naval forces, the participants were subjected to murderous pressure in a pressure chamber, simulating a fall from a great height, and immersed in ice-cold water to understand the limits of human survival in this environment. They were murdered for the purpose of replenishing the collection of skulls justifying superiority of the German race; forcibly sterilized, vaccinated, infected with typhus and yellow fever; had their limbs cut off and implanted to others, which ended in painful death of both the donor and the recipient. The effect of chemical weapons , phosgene and mustard gas, was investigated on living people, same as the medicinal properties of sulfonamides. For the latter purpose, test subjects had their bones crushed and phlegmons induced, broken glass and rusty nails poured into their wounds. The scope of the forced euthanasia program was terrifying. This program was aimed at "cleansing" out the people whom the Nazis considered unworthy, i.e. the disabled, people with chronic diseases, mental and other disabilities. At least 100000 people were proven violently killed under this program, with the predominant kill pattern being phenol injection to the heart. However, since most of the documents were destroyed, the researchers suggest that the number of victims of this program could have actually amounted to about 1 million people and more [2].

The only woman among the convicts was Dr. Gertha Oberheuser, who, like Dr. Karl Brandt, the main accused, Hitler's personal doctor and curator of the inhuman medical experiments, justified her actions by orders of the leadership. In this connection, the Nuremberg Trials declared it was unacceptable to justify the cruelty, inhuman attitude of a medical worker to a patient and any person by orders that violate the "Do no harm" principle. The code adopted in Nuremberg stated that "it is a personal duty and responsibility which may not be delegated to another with impunity" [3].

The basic principle formulated by the Nuremberg Tribunal in the context of the Nuremberg Trials, is that in order to conduct an experiment on a person, a voluntary informed consent should be received from this person after he/she has been provided with full information about the nature, duration and purpose of the experiment, methods of its implementation, the alleged inconveniences and dangers associated with the experiment, and, finally, about the possible physical or mental consequences that may arise as a result of participation in the experiment [3]. It was the first time in the history of mankind when the principle of voluntary informed consent was proclaimed. In the field of medicine, paternalism was replaced by respect for dignity and human rights in making health-related decisions, this respect ensured by the process of obtaining voluntary informed consent $(\mathrm{VIC})$. Medical ethics saw the doctor-patient relationship undergo qualitative changes.
The principles formulated in the Nuremberg Code became the basis for many international and national laws in the field of medical research involving human beings.

In Russia, part 2 of Article 21 of the Basic Law, the Constitution of the Russian Federation, proclaims that "No one should be subjected to torture, violence, other cruel or degrading treatment or punishment. No one can be subjected to medical, scientific or other experiments without voluntary consent" [4]. It follows from this statement that medical experiments carried out on a person fall under the category of torture, violence, cruelty and treatment that degrades human dignity. In Fundamentals of the Russian Federation Law "On the Protection of Citizens' Health", the principles of the Nuremberg Code are reflected in Article 32, which establishes the need for voluntary informed consent to any medical intervention, and in Article 43, which requires the same for medical experiments. In particular, it reads: "Any biomedical research involving a person as an object can be carried out only after obtaining the written consent of this citizen. A citizen cannot be forced to participate in biomedical research.

In the context of obtaining consent for biomedical research, the citizen should be provided with information about the goals, methods, side effects, possible risks, duration and expected results of the research. The citizen has the right to refuse to participate in the research at any stage" [5].

The Nuremberg Code had a significant impact on the subsequent development of a number of international documents that played an important role in the formation of the post-war world order. One of these documents is the Universal Declaration of Human Rights adopted by the UN General Assembly on December 10, 1948 [6].

A year earlier, the global medical community united into the World Medical Association (WMA) at its first general assembly in Paris (September 1947). A kind of the world medical parliament was created, one uniting doctors of the world and setting international standards for medical activity, binding on medical professionals of all countries. The WMA Code of Medical Ethics was influenced by the Nuremberg Code; it includes the main provisions thereof. Together with the Nuremberg Code, the WMA Code supported widespread adoption and application of the principle of VIC. For more than seven decades that followed, WMA became the center spreading the ethical principles applied in healthcare and medicine. Another important milestone is adoption of the Declaration of Geneva, a modern version of the Hippocratic Oath, which took place at the second general assembly of the WMA in Geneva in September 1948. The Declaration of Geneva and the ethical principles applied in medicine were supplemented at the WMA assemblies in Helsinki (1964), Tokyo (1975), Venice (1983), Hong Kong (1989), South Africa (1996), Edinburgh (2000), Washington (2002), Tokyo (2004), Seoul (2008), Brazil (2013). The mere listing of these assemblies testifies to the importance of ethical issues in professional discussions held within the world medical community.

The Nuremberg Code and the Universal Declaration of Human Rights formed the basis for the development of the Universal Declaration on Bioethics and Human Rights, a fundamental document prepared by the UNESCO experts and adopted at the UNESCO General Conference session of October 19, 2005. The Russian philosophers B.G. Yudin and R.G. Apresyan made a great contribution to the preparation of this comprehensive document. The Declaration considers ethical principles quite broadly, reflecting the activities of human beings all around. The key principles stated in the Declaration are covered in its main articles: 
Article 3 - Human dignity and human rights.

Article 4 - Benefit and harm.

Article 5 - Autonomy and individual responsibility.

Article 6 - Consent.

Article 7 - Persons without the legal capacity to consent.

Article 8 - Respect for human vulnerability and personal integrity.

Article 9 - Privacy and confidentiality.

Article 10 - Equality, justice and equity.

Article 11 - Non-discrimination and non-stigmatization.

Article 12 - Respect for cultural diversity and pluralism.

Article 13 - Solidarity and cooperation.

Article 14 - Social responsibility and health.

Article 15 - Sharing of benefits.

Article 16 - Protecting future generations.

Article 17 - Protection of the environment, the biosphere and biodiversity.

The sections covering environmental ethics were included for the first time. Bioethics includes a variety of human activities and their ethical aspects: availability of medical care, clinical research, reproductive health, genome editing and human cloning, donation ethics, environmental ethics, biotechnology and nanotechnology [7].

Intergovernmental and expert committees on bioethics were established within UNESCO. Their activity is guided by the dignity and respect principle formulated in the Nuremberg Code. It should be emphasized here that this principle underpins each fundamental international document in the field of medical ethics.

Also noteworthy are the ethical principles of scientific research developed in the United States of America. In 1974, the US National Commission for the Protection of Human Subjects of Biomedical and Behavioral Research was tasked with defining the fundamental ethical criteria for such research efforts. In 1979, the specialists that tackled the task presented the Belmont Report, the main provisions of which are:

1. Respect of persons.

2. Beneficence.

3. Justice.

Currently, the Belmont Report is the key source of ethical principles for research in the United States.

Ethical problems became especially urgent in the 21st century. The agenda was extended with the ethical challenges peculiar to the present, those related to artificial intelligence, human genome editing and the new patterns of parenting. XXI.

The infectious diseases of the 21 st century are of particular urgency. Human kind faced SARS (2002), MERS (2012), COVID-19 caused by SARS-COV-2 for the first time in its history. It is believed that coronavirus mutations are behind all these vital diseases. The 2009 influenza pandemic should also be mentioned in the list of this century's infectious diseases. The causative agent of that influenza was the California strain of H1N1. The pandemic was the first time when it was found to circulate in the human population. Some other diseases causing grave concern are the Ebola fever and the Zika disease, the former spread in Africa and the latter in Latin America. There is also another topic discussed hotly in the same context as the new infectious diseases: re-emergence of the "old" infections (smallpox etc). These new challenges to civilization highlight human vulnerability and raise questions about the moral foundations of the modern society. In the way of reaction thereto, in May of 2020 there was published the Guide to Informed Consent Compliance [9]. This document covers current approaches to the interpretation of the concept of VIC.XXI
The urgency of this matter is also driven by the need for large-scale studies triggered by the COVID-19 pandemic. The scope and intensity of the relevant research efforts are unprecedented. They have to do with infectious disease epidemiology, prevention, antiviral therapy, pneumonia therapy and intensive care methods, as well as testing of the next generation vaccines. There arose a number of ethical questions that were widely discussed not only by the professional medical community but by the general public, too. In this regard, the relevance of voluntary informed consent has come to the foreground, emphasizing the need to strictly observe the traditional ethical principles of medical treatment: Primum non necere! (First of all, do no harm!) Voluntas aegroti suprema lex! (The patient's will is the highest law!) Salus aegroti suprema lex! (The patient's well-being is the highest law!)

All activities of all medical professionals should pursue interests of the sick person. In this connection, it is also necessary to abandon paternalism for the principle of voluntary informed consent. Hereafter, we consider the semantic component of each of these keywords in detail.

"Voluntary" implies a deep respect for the dignity of the human person, his/her rights and freedoms, the possibility of independent choice. Article 3 of the Declaration on Bioethics and Human Rights addresses human dignity. It is an intrinsic value of a person capable of thinking, feeling, communicating verbally, choosing freely, independent behavior and creative activity. Ethics is the science studying the human being (N.A. Berdyaev); human dignity is a goal in itself. Different cultural and moral traditions and different types of societies have different understandings of the human dignity. In the academic dictionary of the Russian Academy of Sciences, dignity's definition states it is the person's awareness of his high value as a member of a group, which makes this person behave as a member of this group should behave. As an ethical concept, "voluntary" also includes the legal side. There is but a fine line between right and duty, so it is important to return to the interpretation of the person's dignity and his/her behavior as a member of the group to which he/she belongs.

Voluntary decision-making implies the person making the decision is under no external pressure and can make the health-related decisions freely. Thus, "voluntary" implies respect for the person's dignity, his/her rights and obligations, and for the fact that he/she makes his decisions as a free person. Analyzing the problem of freedom, Fedor Dostoevsky defined it as follows: freedom is not restraining oneself, but controlling oneself. N.A. Berdyaev, the philosopher of freedom, relies on the Dostoevsky's definition of freedom and adds that ethics is the philosophy of freedom.

Finally, "voluntary" implies person's autonomy and individual responsibility. Article 5 of the Declaration on Bioethics and Human Rights covers the concepts of autonomy and responsibility.

Autonomy is the person's self-determination ability, independent decisions, actions and assessments. Autonomy implies freedom from paternalistic interference, the person's ability to act on the basis of rational principles and rules in accordance with how this person understands his own good, personal dignity and happiness. According to Kant, autonomy is the ability of the will to independently establish the law of its action. Under the utilitarian approach, autonomy is the ability of a person to act in accordance with his/her own preferences.

The second part of Article 5 is about liability. Responsibility is a person's awareness of the duty to make decisions, act appropriately to his/her obligations, for example, to parents. 
In ethics, the concepts of autonomy and responsibility are interconnected. If there is no responsibility, autonomy turns into arbitrariness: making a decision, a person does not take into account the interests of others.

Thus, the term "voluntary" should, first of all, mean respect for the dignity of the human person, his/her rights and freedom, as well as autonomy and responsibility.

The very text of the VIC is what its preparation revolves about. This document should not be considered as a piece of paper that needs a signature, i.e. as some formal procedure. Naturally, the question arises as to who is the author of this document: the sponsor, the scientific leader of the project, the organization of sick patients? Initially, the drafting of the document is initiated by the sponsor and reviewed at the topical expert meeting with participation of the scientific leader. The next important stage is the approval of the document. The preference should be given to the science and practice societies (several of them, in some cases) that can approve the VIC text. However, such a society needs to have a body authorized to approve the such a text. In the US, for example, the US Food and Drugs Administration (FDA) includes the Institution Review Board (IRB), which has approval of VIC texts among its duties. The Association of American Physicians also plays an important role. Finally, the relevant ethics committee reviews the VIC text at a meeting. The ethics committee experts review the suggested study as a whole, but they pay special attention to the said text. Practice shows that this part of a research project is the most vulnerable. The experience of international pharmaceutical companies can serve as a benchmark. As for the Russian research projects, in this part they usually contain comments from the ethics committee. The reason is that both the sponsor and the scientific leaders of the project typically lack the required skill, which translates into the need to train them to compile the informed consent texts.

The basis element of the informed consent is the part that details purpose of the study, its duration and research procedures.

An important section of the VIC is the description of the possible adverse reactions. In some studies, it is necessary to consider adverse reactions to treatment or instrumental examinations. This part of the document should be carefully analyzed by experts and explained to the patient in an understandable and accessible form. The witness is responsible for controlling how clearly the doctor explains the details of the $\mathrm{VIC}$ to a sick person or to his family members and other persons responsible for the sick person. The involvement of the witness, as mentioned above, is a relatively new condition for the VIC document. The informed consent witness must be convinced that the doctor has described the possibility of development of adverse reactions in an understandable manner, and that the patient has understood them. This is the role of the witness. $\mathrm{He} /$ she should note in the document that the VIC process was carried out professionally and in compliance with the established requirements.

When considering a research project, the doctor should also discuss with the patient the benefits that the latter receives from participating in this research or from application of the certain methods of treatment and examination.

The participating person's financial interest occupies a special place. Before enrolling, he/she must receive clear and concise information regarding the financial compensation for the participation. Moreover, the participant should have the right to leave the study at any stage thereof.

Current requirements for the text of informed consent allow two forms thereof: a detailed text and a short form, with declaration of the project itself and the objectives of the study.
In some special cases, a life-threatening disease may necessitate VIC acceleration. This is a state-level decision made by the healthcare authorities. A case in question is that of registration of the new generation vaccines designed to prevent spread of SARS-COV-2: the circumstances called for a shorter vaccine testing procedure than is usually customary. Another special case is obtaining a VIC from persons who, for various reasons, cannot make decisions on their own. First of all, this applies to patients with impaired cognitive function.

Ethical issues permeate the entire process of developing and passing the voluntary informed consent to practice. The ethical aspects of placebo and nocebo must be emphasized. The latter problem is rarely covered in Russian literature. The nocebo effect is the process of deterioration of the patient's health under the influence of information that is communicated to him/her by the doctor or medical personnel. There are following forms of nocebo distinguished: psychosomatic health deterioration caused by the expected adverse reactions; psychosomatic deterioration manifesting in the desire to have health deteriorating and, finally, actual deterioration of health of the patient due to the his/her initial attitude to such a turn of events. Unfortunately, current studies do not factor in and analyze the effects of placebo and nocebo sufficiently, which is especially relevant for the latter.

It is no coincidence that the article emphasizes the historical role of the Nuremberg Code, which formed the basis of the Universal Declaration of Human Rights, the WMA International Code of Medical Ethics, the Declaration on Bioethics and Human Rights, which are the documents that largely determined the current world order. Highlighting the importance of the principle of voluntary informed consent, it is necessary to underline the need for state-level consideration of the bioethics problems. This is the only way to ensure the unity and integrity of state policy and decisions made in this important area, which stretches beyond the scopes of responsibility of individual ministries and departments.

Apparently, US President Bill Clinton followed similar logic when he established the National Bioethics Advisory Commission under his auspices in 1996. In 2001, under US President George W. Bush, the status of the Commission was advanced, its powers expanded. Executive Order 13237 of November 28, 2001 transformed the National Commission into the President's Council on Bioethics. Its members and president, Edmund D. Pellegrino, the famous American scientist and theorist of bioethics, were personally appointed by the President of the United States. The council was supposed to "advise the president on bioethical issues that may arise from advances in biomedical science and technology" [9].

Barack Obama's Order 13521 of November 24, 2009, boosted the status of the body further up and turned it into the Presidential Commission for the Study of Bioethical Issues, which became interdepartmental and received powers, outgrowing its purely philosophical leadership. Amy Gutmann, President of the University of Pennsylvania, was appointed Chairman of the Commission [9]. Shortly thereafter, the information on the Commission's activities became all but inaccessible to the general public, which, according to experts, may indicate the seriousness of the issues discussed and the proposals developed for the President of the United States.

The ethical challenges of the century, having shown the relevance of the lessons of Nuremberg, raised the issues of ethical education of society and ethical assessment of events unfolding in the world. The solution of the problems the society faces is largely associated with the development of bioethics that, in the conditions of the current changing world, is of particular importance to the national security of the Russian state. 


\section{References}

1. Die Nürnberger Prozesse. Sandberg Verlag. Nürnberg. 2008. ISBN 978-3-930699-52-0.

2. Mitscherlich A, Mielke F. Medizin ohne Menschlichkeit: Dokumente des Nürnberger Ärzteprozesses, 16. Aufl., Heidelberg: Fischer 2004. ISBN 978-3-596220-03-8.

3. Pravovye dokumenty. Njurnbergskij kodleks. http://www. psychepravo.ru/law/int/nyurnbergskij-kodeks.htm/Russian.

4. Konstitucija Rossijskoj Federacii, stat'ja 21, chast' 2. http://www. consultant.ru/document/cons_doc_LAW_28399/e7fbd40d5c89 c3066eab2473bcaac30880b58eb3/Russian.

5. Osnovy zakonodatel'stva Rossijskoj Federacii «Ob ohrane zdorov'ja grazhdan». Stat'i 32 i 43. https://rg.ru/1993/08/19/

\section{Литература}

1. Die Nürnberger Prozesse. Sandberg Verlag. Nürnberg. 2008. ISBN 978-3-930699-52-0.

2. Mitscherlich A, Mielke F. Medizin ohne Menschlichkeit: Dokumente des Nürnberger Ärzteprozesses, 16. Aufl., Heidelberg: Fischer 2004. ISBN 978-3-596220-03-8.

3. Правовые документы. Нюрнбергский кодекс. http://www. psychepravo.ru/law/int/nyurnbergskij-kodeks.htm/

4. Конституция Российской Федерации, статья 21, часть 2. http://www.consultant.ru/document/cons_doc_LAW_28399/e7f bd40d5c89c3066eab2473bcaac30880b58eb3/

5. Основы законодательства Российской Федерации «Об охране здоровья граждан». Статьи 32 и 43. https://rg.ru/1993/08/19/ osnovy-zdorovya-dok.html/ osnovy-zdorovya-dok.html/ Russian.

6. Vseobshhaja Deklaracija Prav Cheloveka. https://www.un.org/ru/ documents/decl_conv/declarations/declhr.shtml/Russian.

7. Vseobshhaja deklaracija o biojetike i pravah cheloveka Prinjata rezoljuciej General'noj konferencii JuNESKO 19 oktjabrja 2005 goda. https://www. un.org/ru/documents/decl_conv/declarations/bioethics_and hr.shtml/

8. Guide to Informed Consent Compliance. Washington, USA. Publication date: May 2020. Page count: 705 ISBN-13:978-160430-136-6 https://www.centerwatch.com/products/476-guideto-informed-consent-compliance/

9. Prezidentskij sovet po biojetike SShA. https://ru.qaz.wiki/wiki/ The_President\%27s_Council_on_Bioethics/Russian.

6. Всеобщая Декларация Прав Человека. https://www. un.org/ru/documents/decl_conv/declarations/declhr. shtml/

7. Всеобщая декларация о биоэтике и правах человека Принята резолюцией Генеральной конференции ЮНЕСКО 19 октября 2005 года. https://www.un.org/ru/documents/decl_ conv/declarations/bioethics and hr.shtml/

8. Guide to Informed Consent Compliance. Washington, USA. Publication date: May 2020. Page count: 705 ISBN-13:978-160430-136-6 https://www.centerwatch.com/products/476-guideto-informed-consent-compliance/

9. Президентский совет по биоэтике США. https://ru.qaz.wiki/ wiki/The_President\%27s_Council_on_Bioethics/ 